\title{
Methane Production in-vitro and Dry Matter Digestibility as Influenced by Linseed Oil Supplementation in Buffaloes
}

\author{
A.P. Dhok* , A.D. Deshmukh, R.N. Dhore and N.V. Kurkure \\ Department of Animal Nutrition, Nagpur Veterinary College, Nagpur - 440006 (MS), \\ (Maharashtra Animal \& Fishery Sciences University, Nagpur), India \\ *Corresponding author
}

\begin{abstract}
A B S T R A C T
The study was conducted to develop the methane mitigation through lipid supplementation in buffaloes. Linseed oil was used in the concentrate mixture and five different concentrate mixtures were prepared using $0,1,2,3$ and 4 percent linseed oil. The combinations were made of these concentrate mixtures with gram straw in the ratio of 10:90 to 90:10 for straw: concentrate mixture and evaluated for in-vitro methane production and in-vitro dry matter digestibility. The methane production was significantly lower and dry matter digestibility was significantly better on 70:30 and 60:40 gram straw to concentrate combination, where linseed oil was included at one percent in concentrate mixture. The addition of linseed oil in concentrate mixture at two percent level could be effective in methane inhibition as well enhancing dry matter digestibility at higher levels of gram straw i.e. 60 and 70 in combination to concentrates, however linseed oil at one percent level with roughage to concentrate ratio maintained at $70: 30$, could be economical strategy of methane mitigation in buffaloes. The higher level of linseed oil in concentrate mixture inhibited methane significantly but dry matter digestibility could not be enhanced to that extent. It is concluded that gram straw and concentrate mixture having linseed oil at one percent level with roughage to concentrate ratio maintained at 70:30, could be economical strategy of methane mitigation in buffaloes.
\end{abstract}

\section{Introduction}

The production of Animal protein always comes with the production of greenhouse gases (GHG). The ruminant supply chains are estimated to produce 5.7 giga tonnes $\mathrm{CO}_{2}-$ equivalent per year and about $80 \%$ from the livestock sector emission. The largest source of $\mathrm{GHG}$ emission in ruminant production is methane coming from the enteric fermentation and accounts for about $47 \%$ of the sector emission and more than $90 \%$ of the total methane emission. Methane is one of the potent greenhouse gas produced from paddy fields and from enteric fermentation of the ruminants. It is a colourless, odourless, heavy, highly inflammable, hydrocarbon, relatively more potent having 100 years global warming potential. It is 23 times more effective in trapping heat than $\mathrm{CO}_{2}$, which remains in atmosphere for 9 - 15 years and its chemical lifetime is of 12 years (IPCC, 2001). An adult cow emits about 80-120 kg methane /yr, making 8-12\% loss in gross energy. Indian 
livestock produce $14 \%$ of global emission $11 \mathrm{Tg}(\mathrm{mt}) / \mathrm{yr}$, mainly due feeding system (low quality roughages, acetate, methane).

Addition of oils to ruminant diets may decrease methane emission by two mechanisms; the indirect mechanism includes protozoal inhibition, reduction of double bonds in unsaturated fatty acids, increased productivity and enhanced propionate production. Fatty acid toxicity to methanogens is the direct mechanism. Indirect effects of oils, which ultimately result in methane reduction, have been reported by many workers. The suppressive effect of long chain unsaturated fatty acids on methanogenesis demonstrated the competition between methanogenesis and bio-hydrogenation process. However, fats and oils supplemented in higher levels can have negative effects on the animals also such as reduction in fibre digestibility. Hence considering the benefits as well limitations, efforts were made to use linseed oil judiciously to develop methane mitigation strategies.

\section{Materials and Methods}

Linseed oil was used in the concentrate mixture and five different concentrate mixtures were prepared using $0,1,2,3$ and 4 percent linseed oil. The combinations were made of these concentrate mixtures with gram straw in the ratio of 10:90 to $90: 10$ for straw: concentrate mixture and evaluated for in-vitro methane production as per Menke et al., (1979) and in-vitro dry matter digestibility as per Van Soest and Robertson, (1976). The Menke in vitro gas-production technique has been used to determine the amount of gas produced over a 24-hour incubation period with $200 \mathrm{mg}$ sample incubated in glass syringe. Fermentation is carried out in this glass syringe. The rumen liquor was collected in an insulated jar just 15 minutes before the trial starts. The collected rumen fluid was filtered through double layer of cheese cloth into a warm flask (kept in a bucket of water at $37-38^{\circ} \mathrm{C}$ ) and flushed with carbon dioxide. The buffer medium was prepared with distilled water adding micro mineral solution, buffer solution, macro mineral solution, reducing solution and resazurin. Then the rumen fluid was added and ratio of rumen fluid to buffer medium is $1: 2(\mathrm{v} / \mathrm{v})$. Thirty $\mathrm{ml}$ of such medium was pipetted with an automatic syringe into each of the pre-warmed glass syringes having $200 \mathrm{mg}$ sample. The syringes were then placed for incubation in the water bath at $38-39^{\circ} \mathrm{C}$. The total gas production was measured at $24 \mathrm{hrs}$. The gaseous samples were injected with gas-tight glass-syringes with a volume of $1 \mathrm{ml}$. The Flame ionization detector (FID) was used for the methane estimation. The data obtained were analysed statistically as per Snedecor and Cochran (1994).

\section{Results and Discussion}

Linseed oil was used in the concentrate mixture and five different concentrate mixtures were prepared using $0,1,2,3$ and 4 percent linseed oil. The combinations were made of these concentrate mixtures with gram straw in the ratio of 10:90 to $90: 10$ for straw: concentrate mixture and evaluated for in-vitro methane production and in-vitro dry matter digestibility (Table 1). At higher levels of gram straw i.e. 80 and 90 percent, the methane production was higher and seems to be reducing as the share of straw decreased. However the methane production was significantly lower on 90 percent concentrate level with 10 percent gram straw and it was comparable with 70:30 and 60:40 gram straw to concentrate combination. Similar trend was seen with methane per $100 \mathrm{mg}$ of digestible dry matter; however it was significantly lower on 70:30 gram straw concentrate combination, indicated positive role of linseed in methane inhibition even at higher levels of gram straw. 
Table.1 Methane emission and in-vitro dry matter digestibility on different combinations of concentrate mixture and gram straw with linseed oil

\begin{tabular}{|c|c|c|c|}
\hline $\begin{array}{l}\text { Combinations } \\
\text { GS: Conc. }\end{array}$ & $\begin{array}{l}\mathrm{CH}_{4} \\
(\mathrm{ml}) \\
\end{array}$ & $\begin{array}{c}\text { IVDMD } \\
(\%)\end{array}$ & $\begin{array}{c}\mathrm{CH}_{4} \\
(\mathrm{ml} / 100 \mathrm{mg} \text { DDM }) \\
\end{array}$ \\
\hline \multicolumn{4}{|c|}{ Gram Straw and Concentrate Mixture } \\
\hline $10: 90$ & $3.52^{\mathrm{a}} \pm 0.06$ & $70.96^{\mathrm{de}} \pm 1.17$ & $2.48^{\mathrm{a}} \pm 0.05$ \\
\hline $20: 80$ & $3.66^{\mathrm{a}} \pm 0.09$ & $70.17^{\mathrm{de}} \pm 0.26$ & $2.60^{\mathrm{a}} \pm 0.03$ \\
\hline 30:70 & $3.68^{\mathrm{a}} \pm 0.03$ & $71.81^{\mathrm{e}} \pm 0.86$ & $2.56^{\mathrm{a}} \pm 0.02$ \\
\hline 40:60 & $3.96^{\mathrm{b}} \pm 0.11$ & $71.04^{\mathrm{de}} \pm 0.44$ & $2.78^{\mathrm{b}} \pm 0.09$ \\
\hline 50:50 & $4.12^{\mathrm{bc}} \pm 0.02$ & $67.26^{\mathrm{cd}} \pm 1.13$ & $3.06^{\mathrm{c}} \pm 0.03$ \\
\hline $60: 40$ & $4.08^{\mathrm{bc}} \pm 0.04$ & $64.43^{\mathrm{c}} \pm 0.19$ & $3.16^{\mathrm{c}} \pm 0.06$ \\
\hline $70: 30$ & $4.19^{c} \pm 0.09$ & $59.72^{\mathrm{b}} \pm 1.87$ & $3.50^{\mathrm{d}} \pm 0.10$ \\
\hline $80: 20$ & $7.04^{\mathrm{d}} \pm 0.11$ & $48.71^{\mathrm{a}} \pm 0.77$ & $7.22^{\mathrm{e}} \pm 0.09$ \\
\hline 90:10 & $7.52^{\mathrm{e}} \pm 0.13$ & $45.39^{\mathrm{a}} \pm 1.09$ & $8.28^{\mathrm{f}} \pm 0.19$ \\
\hline \multicolumn{4}{|c|}{ Gram Straw and Concentrate Mixture having $1 \%$ linseed oil } \\
\hline $10: 90$ & $2.48^{\mathrm{a}} \pm 0.09$ & $79.14^{\mathrm{d}} \pm 0.96$ & $1.56^{\mathrm{a}} \pm 0.02$ \\
\hline $20: 80$ & $2.84^{\mathrm{b}} \pm 0.02$ & $75.17^{\mathrm{cd}} \pm 0.78$ & $1.75^{\mathrm{b}} \pm 0.05$ \\
\hline $30: 70$ & $2.81^{\mathrm{b}} \pm 0.05$ & $76.22^{\mathrm{d}} \pm 1.01$ & $1.71^{\mathrm{b}} \pm 0.06$ \\
\hline $40: 60$ & $3.66^{\mathrm{d}} \pm 0.11$ & $72.16^{\mathrm{c}} \pm 0.22$ & $2.53^{\mathrm{d}} \pm 0.09$ \\
\hline $50: 50$ & $3.01^{\mathrm{c}} \pm 0.06$ & $77.84^{\mathrm{d}} \pm 1.07$ & $1.93^{\mathrm{c}} \pm 0.03$ \\
\hline $60: 40$ & $2.67^{\mathrm{a}} \pm 0.07$ & $85.00^{\mathrm{e}} \pm 0.79$ & $1.57^{\mathrm{a}} \pm 0.04$ \\
\hline $70: 30$ & $2.52^{\mathrm{a}} \pm 0.09$ & $83.42^{\mathrm{e}} \pm 0.66$ & $1.51^{\mathrm{a}} \pm 0.09$ \\
\hline $80: 20$ & $4.22^{\mathrm{e}} \pm 0.10$ & $62.19^{\mathrm{b}} \pm 1.17$ & $3.39^{\mathrm{e}} \pm 0.08$ \\
\hline 90:10 & $4.18^{\mathrm{f}} \pm 0.11$ & $54.12^{\mathrm{a}} \pm 0.96$ & $3.86^{\mathrm{f}} \pm 0.10$ \\
\hline \multicolumn{4}{|c|}{ Gram Straw and Concentrate Mixture having 2\% linseed oil } \\
\hline $10: 90$ & $2.32^{\mathrm{a}} \pm 0.02$ & $80.26^{\mathrm{e}} \pm 0.84$ & $1.44^{\mathrm{a}} \pm 0.02$ \\
\hline $20: 80$ & $2.64^{\mathrm{bc}} \pm 0.11$ & $79.14^{\mathrm{de}} \pm 2.12$ & $1.66^{\mathrm{b}} \pm 0.04$ \\
\hline $30: 70$ & $2.52^{\mathrm{b}} \pm 0.05$ & $78.86^{\mathrm{de}} \pm 0.77$ & $1.59^{\mathrm{b}} \pm 0.02$ \\
\hline 40:60 & $3.01^{\mathrm{d}} \pm 0.13$ & $74.79^{c} \pm 0.41$ & $2.01^{\mathrm{d}} \pm 0.02$ \\
\hline $50: 50$ & $2.86^{\mathrm{cd}} \pm 0.09$ & $76.82^{\text {cd }} \pm 0.96$ & $1.86^{\mathrm{c}} \pm 0.09$ \\
\hline $60: 40$ & $2.56^{\mathrm{b}} \pm 0.03$ & $80.06^{\mathrm{e}} \pm 1.19$ & $1.59^{\mathrm{b}} \pm 0.06$ \\
\hline $70: 30$ & $2.50^{\mathrm{ab}} \pm 0.07$ & $84.84^{\mathrm{f}} \pm 2.06$ & $1.47^{\mathrm{a}} \pm 0.07$ \\
\hline $80: 20$ & $3.26^{\mathrm{e}} \pm 0.09$ & $61.42^{\mathrm{b}} \pm 1.77$ & $2.65^{\mathrm{e}} \pm 0.09$ \\
\hline 90:10 & $3.71^{\mathrm{f}} \pm 0.06$ & $57.26^{\mathrm{a}} \pm 0.17$ & $3.23^{\mathrm{f}} \pm 0.11$ \\
\hline \multicolumn{4}{|c|}{ Gram Straw and Concentrate Mixture having 3\% linseed oil } \\
\hline $10: 90$ & $2.40^{\mathrm{a}} \pm 0.06$ & $77.12^{\mathrm{c}} \pm 2.24$ & $1.55^{\mathrm{a}} \pm 0.01$ \\
\hline $20: 80$ & $2.52^{\mathrm{a}} \pm 0.02$ & $77.06^{\mathrm{c}} \pm 0.21$ & $1.63^{\mathrm{a}} \pm 0.09$ \\
\hline $30: 70$ & $2.84^{\mathrm{b}} \pm 0.07$ & $76.12^{\mathrm{bc}} \pm 0.96$ & $1.85^{\mathrm{b}} \pm 0.07$ \\
\hline $40: 60$ & $3.01^{\mathrm{c}} \pm 0.11$ & $74.00^{\mathrm{b}} \pm 0.77$ & $2.03^{\mathrm{c}} \pm 0.11$ \\
\hline$\overline{50: 50}$ & $3.06^{\mathrm{c}} \pm 0.09$ & $74.16^{\mathrm{b}} \pm 1.01$ & $2.06^{\mathrm{c}} \pm 0.03$ \\
\hline 60:40 & $2.84^{\mathrm{b}} \pm 0.04$ & $75.26^{\mathrm{bc}} \pm 0.84$ & $1.88^{\mathrm{b}} \pm 0.06$ \\
\hline $70: 30$ & $2.91^{\mathrm{bc}} \pm 0.02$ & $76.71^{\mathrm{bc}} \pm 0.99$ & $1.89^{\mathrm{b}} \pm 0.04$ \\
\hline $80: 20$ & $3.26^{\mathrm{d}} \pm 0.05$ & $56.12^{\mathrm{a}} \pm 0.17$ & $2.90^{\mathrm{d}} \pm 0.07$ \\
\hline 90:10 & $3.44^{\mathrm{e}} \pm 0.09$ & $54.43^{\mathrm{a}} \pm 1.66$ & $3.16^{\mathrm{e}} \pm 0.11$ \\
\hline \multicolumn{4}{|c|}{ Gram Straw and Concentrate Mixture having 4\% linseed oil } \\
\hline $10: 90$ & $2.26^{\mathrm{a}} \pm 0.01$ & $69.00^{c} \pm 0.67$ & $1.63^{\mathrm{a}} \pm 0.09$ \\
\hline $20: 80$ & $2.44^{\mathrm{b}} \pm 0.02$ & $69.06^{c} \pm 0.29$ & $1.76^{\mathrm{b}} \pm 0.05$ \\
\hline $30: 70$ & $2.52^{\mathrm{b}} \pm 0.06$ & $70.84^{\mathrm{c}} \pm 0.16$ & $1.77^{\mathrm{b}} \pm 0.07$ \\
\hline $40: 60$ & $2.48^{\mathrm{b}} \pm 0.11$ & $69.04^{\mathrm{c}} \pm 0.94$ & $1.79^{\mathrm{b}} \pm 0.11$ \\
\hline $50: 50$ & $2.79^{c} \pm 0.09$ & $71.84^{\mathrm{c}} \pm 1.03$ & $1.94^{\mathrm{c}} \pm 0.06$ \\
\hline $60: 40$ & $2.84^{c} \pm 0.07$ & $66.26^{\mathrm{b}} \pm 0.79$ & $2.14^{\mathrm{d}} \pm 0.02$ \\
\hline $70: 30$ & $2.96^{\mathrm{c}} \pm 0.05$ & $66.99^{b} \pm 1.06$ & $2.20^{\mathrm{d}} \pm 0.08$ \\
\hline $80: 20$ & $3.26^{\mathrm{d}} \pm 0.11$ & $51.77^{\mathrm{a}} \pm 0.97$ & $3.14^{\mathrm{e}} \pm 0.04$ \\
\hline 90:10 & $3.24^{\mathrm{d}} \pm 0.03$ & $50.96^{\mathrm{a}} \pm 1.69$ & $3.17^{\mathrm{e}} \pm 0.10$ \\
\hline
\end{tabular}


The IVDMD was also significantly better in 70:30 and 60:40 gram straw to concentrate combination when linseed oil was added at 1 percent level in concentrate mixture. The methane production was significantly reduced at higher concentrate levels; however it was comparable with 70:30 gram straw and concentrate having 2 percent linseed oil. The methane emission per $100 \mathrm{mg}$ digestible dry matter was also lower on 70:30 roughage to concentrate having 2 percent linseed oil. The addition of linseed oil in concentrate mixture at 2 percent level could be effective in methane inhibition as well enhancing digestibility at higher levels of gram straw i.e. 60 and 70 in combination to concentrates. Significantly higher methane inhibition was seen due to concentrate mixture having 3 and 4 percent linseed oil and the effect was diminishing as the concentrate level reduces. Even at higher level of gram straw i.e. 80 and 90 percent in combination to concentrate, methane production could not be elevated due to addition of linseed oil at 3 percent level. The similar findings were reported by Martin et al., (2008) who supplemented linseed oil in dairy cows. The findings are consistent with Beauchemin et al., (2008) who reported 13\% methane reduction without affecting digestibility due to addition of flax seed contributing $3.1-4.2 \%$ fat to the diet of dairy cow.

The findings are in consonance with Vergas et al., (2011), who observed increased dry matter, organic matter and NDF disappearance due to supplementation of linseed oil. The methane production was also reduced significantly than control producing more propionate type of fermentation. They attributed the methane reduction to that, the lipid supplementation of diets reduces methane emissions by inhibiting organic matter fermented in the rumen, activity of methanogenic archea or ruminal protozoa, and through the disposal of hydrogen during the fatty acid biohydrogenation process. Eugene et al., (2011) also concluded that supplementation with extruded linseed lipids combined with starch in feedlot diet decreased enteric $\mathrm{CH}_{4}$ emissions. The reduction in methane emission due to supplementation of linseed oil in the present study may be attributed to the fatty acids, which are not fermented in the rumen and do not provide hydrogen and other substrates for methane producing bacteria, as supported by Morgavi et al., (2011). It is concluded that gram straw and concentrate mixture having linseed oil at one percent level with roughage to concentrate ratio maintained at 70:30, could be economical strategy of methane mitigation in buffaloes.

\section{Acknowledgement}

The financial support from Indian Council of Agricultural Research, New Delhi is gratefully acknowledged.

\section{References}

Beauchemin, KA, McGinn, SM, Benchaar, C and Holthausen, L (2008) Crushed sunflower, flax or canola seeds in lactating dairy cow diets: Effects on methane production, rumen fermentation and milk production. $J$. Dairy. Sci., 92(5): 2118-2127.

Eugene, M, Martina, C, Mialona, MM, Kraussb, D, Renandc, G and Doreaua, M (2011) Dietary linseed and starch supplementation decreases methane production of fattening bulls. Anim. Feed Sci. Technol. doi:10.1016/j.anifeedsci.2011.04.023

IPCC, (2001) Intergovernmental Panel on Climate Change, Cambridge University Press, UK.

Martin, C, Rouel, J, Jouany, JP, Doreau, M, and Chilliard, Y (2008) Methane output and diet digestibility in response to 
feeding dairy cows crude linseed, extruded linseed or linseed oil. J. Anim. Sci., 86: 2642-2650.

Menke, K.H., Raab, L, Salewski, A, Steingass, H, Fritz, D, Schneider W (1979) The estimation of the digestibility and metabolizable energy content of ruminant feedstuffs from the gas production when they are incubated with rumen liquor. J. Agric. Sci., 93: 217-222.

Morgavi, DP, Eugene, M, Martin, $\mathrm{C}$ and Doreau, M (2011) Reducing methane emissions in ruminants, is it an available goal? In Ranilla M.J., Carro MD., Ben Salem H, Morand-Fehr P (Ed). Challenging strategies to promote the sheep and goat sector in the current global context. Zaragoza: CIHEAM / CSIC / Universidad de León / FAO pages 163-168.
Snedecor, GW and Cochran, WG (1994) Statistical Methods, $8^{\text {th }}$ Ed. IOWA State University Press, Ames, IOWA

Van Soest, PJ and Robertson, JB (1976) Chemical and physical properties of dietary fibre. In Dietary Fibre; Proceedings of the Miles Symposium

Vargas JE., Andres S, Yáñez Ruiz DR and López S (2011) The effect of olive, sunflower or linseed oils on the fermentation pattern and methane production in the rumen simulating technique In Ranilla MJ, Carro MD, Ben Salem H, Morand-Fehr P (Ed) Challenging strategies to promote the sheep and goat sector in the current global context. Zaragoza: CIHEAM / CSIC / Universidad de León / FAO pages $163-168$

\section{How to cite this article:}

Dhok, A.P., A.D. Deshmukh, R.N. Dhore and Kurkure, N.V. 2018. Methane Production invitro and Dry Matter Digestibility as Influenced by Linseed Oil Supplementation in Buffaloes. Int.J.Curr.Microbiol.App.Sci. 7(09): 2160-2164. doi: https://doi.org/10.20546/ijcmas.2018.709.265 